Ivana Prlić ${ }^{1}$

Visoka škola strukovnih studija

za vaspitače i poslovne informatičare-Sirmium

Sremska Mitrovica
Primljen: 11.10.2020.

Prihvaćen: 10.12.2020.

UDK: 001.1/.19:37.01

DOI 10.19090/ps.2020.2.128-141

\title{
TEORIJA KOMUNIKATIVNOG DELOVANJA: KONTEKST ZA RAZUMEVANJE PRIRODE ZNANJA U PEDAGOGIJI
}

\author{
Apstrakt
}

U radu se razmatra teorija komunikativnog delovanja Jirgena Habermasa kao kontekst za razumevanje prirode znanja u pedagogiji. Polazeći od ideja Frankfurtske škole kritičke teorije Habermas smatra da je znanje vođeno trima različitim interesima: tehničkim, praktičnim i emancipatorskim. Zagovara komunikativnu racionalnost, neprinudno učešće subjekata u komunikaciji u kojoj ih ujedinjuje snaga argumentativnog govora. Veruje da je konsenzus moguć u situaciji idealnog govora, oslobođenoj od svih vidova spoljne moći, nejednakosti i represije. Jedina moć koja važi i odnosi pobedu u komunikaciji je snaga boljeg argumenta. Znanje koje se ustanovi kroz ovaj intersubjektivni akumulativni proces stalno nadograđujućih, nastajućih konsenzusa u puno različitih situacija idealnog govora je vođeno navedenim interesima, pa je znanje uvek interesno znanje u nekoj od tri paradigme. U radu je dalje razmatrano kakvo značenje za pedagogiju imaju neke od ključnih Habermasovih ideja. Kritike koje različiti autori upućuju teoriji komunikativnog delovanja su diskutovane kroz dovođenje u odnos sa određenim stanovištima u pedagogiji. Shodno tome, naročita pažnja posvećena je razumevanju dijaloga u obrazovanju.

Ključne reči: priroda znanja, komunikativna racionalnost, konsenzus, dijalog u obrazovanju

\section{Jirgen Habermas kao predstavnik Frankfurtske škole kritičke teorije}

Jirgen Habermas (1929) je nemački filozof i jedan od najznačajnijih mislilaca današnjice koji je učestvovao u radu Instituta za društvena istraživanja, osnovanom 1923. godine u Frankfurtu. Frankfurtska škola, kritička teorija društva je naziv za ovaj raznorodni krug mislilaca, filozofa, sociologa, pravnika, ekonomista, psihologa, knji-

1 e-mail: vs.ivana.prlic@gmail.com 
ževnika, angažovanih na društvenom projektu oko Instituta i Časopisa za društvena istraživanja (Habermas, 1975; Halmi, 2005; Pavićević, 2011; Ricer, 2012).

Svoj rad zasnovali su na intelektualnoj baštini Marksa, Kanta, Hegela, Hajdegera, Frojda i drugih mislilaca (Flivbjerg, 2012; Pavićević, 2011; Pešić, 1998). Bili su istinski zainteresovani i angažovani oko stvaranja nove teorije društva koja kritikuje to isto društvo i veruje u njegovu promenu. Prepoznali su da je zapadno društvo u krizi, da se ljudska prava ne poštuju i analizirali su postojeće kapitalističko društvo sa ciljem da ga preobraze u bolje i pravednije društvo koje nije zasnovano na tržišnoj ekonomiji koja eksploatiše znanje i čoveka (Habermas, 1982; prema: Rorty, 1991; Halmi, 2005; Terry, 1997).

Shodno tome, Habermas veruje da je moguće razviti univerzalnu racionalnu osnovu društvenih institucija (Flivbjerg, 2012). U svojoj teoriji komunikativnog delovanja pravi otklon od kritike celokupnog društva prema prepoznavanju struktura komunikativne racionalnosti unutar društva što je oličeno u intersubjektivno utemeljenoj teoriji komunikativnog delovanja (Habermas, 1980). Prisutno je poverenje u društvene institucije, zdrav razum, dijalog i bolji argument kroz koji se postiže konsenzus. Fokus se pomera od subjektocentrirane filozofije, instrumentalnog uma ka komunikativnoj intersubjektivnosti, komunikativnom umu (Habermas, 1975; Habermas, 1988; Habermas, 2017a).

\section{Saznanje i interes u kontekstu teorije komunikativnog delovanja}

\section{Dvoslojnost društva - svet života i sistem.}

Habermas smatra da je koncept društva dvoslojan i da se sastoji iz sveta života i sistema (Habermas, 2017b). Kako sam kaže, svet života je mesto susreta govornika i slušaoca „gde uzajamno mogu da pretenduju na to da se njihovi iskazi slažu sa svetom (objektivnim, društvenim ili subjektivnim) i gde ove pretenzije na važenje mogu da kritikuju i potvrđuju, da iznose svoj disens i postižu saglasnost" (Habermas, 2017b: 162). Određuje se kao kolektivno prihvaćeno, neproblematizujuće znanje koje dele pripadnici društva (Habermas, 1988; Habermas, 2017a). Pruža okvir za moguća zajednička tumačenja, kontekst je u komunikativnom delovanju i komplementaran mu je kao resurs pozadinskog znanja za sve učesnike u različitim kooperativnim procesima (Habermas, 1988; Habermas, 2017a; Habermas, 2017b). Time su sagovornici u komunikaciji rezultat nasleđa, obnavljaju nasleđene kulturne obrasce, ali ih i konstruišu, iniciraju delovanja, oblikujući autentični identitet (Habermas, 1988; Habermas, 2017a; Habermas, 2017b). Izdvaja se razumevanje da svet života nije intersubjektivan, već se sagovornici ,,uvek kreću unutar horizonta svoga sveta života, i iz njega ne mogu da iskorače" (Habermas, 2017b: 162). Sa druge strane, nezavisan je od spoljašnjih prinu$d a$ i zato pruža horizont neograničenih mogućnosti sporazumevanja između subjekata koji ističu različite pretenzije na važenje (Habermas, 2017a; Habermas, 2017b). 
Sistem se razvija iz sveta života, ali ima svoj poseban karakter. Uključuje društvene strukture poput države, privrede, pravnog sistema, porodice itd. (Habermas, 2017b; Ricer, 2012). Takođe, sistem i svet života podležu racionalizaciji na sebi svojstven način (Habermas, 2017b), kroz usložnjavanje i veću diferencijaciju sastavnih struktura, odnosno kroz otvorenu i slobodnu komunikaciju (Habermas, 1988; Habermas, 2017b; Ricer, 2012). Racionalizacija sveta života je pretpostavka za usložnjavanje sistema koji tako usložnjen sam sebe na neki način „uništava” jer sve instrumentalizuje i tehnizira (Habermas, 2017b).

Moć sistema koji je usmeren prema kontroli, kolonizaciji sveta života, direktno raste sa povećanjem racionalizacije. Nekada to čini kroz zakone koji zabranjuju otvorenu i slobodnu komunikaciju u svetu života koja vodi konsenzusu (Habermas, 1988; Ricer, 2012). Iako se reprodukcija javne sfere dešava u borbi sistema (ekonomskog, birokratskog, administrativnog) i sveta života (Terry, 1997), kolonizacija je destruktivna po svet života. Osiromašuje i čini komunikaciju rigidnom, jer se suviše oslanja na spoljnog ,kontrolora”, strukture sistema (Habermas, 2017b; Ricer, 2012).

Neprestano traje borba između sistema koji teži da kolonizuje i sveta života koji se kroz otvorenu i slobodnu komunikaciju odupire kolonizatoru. Habermas je protiv jednostrane kolonizacije, a za racionalizaciju, tj. mogućnost da se svaki entitet razvija, usložnjava i diferencira na sebi svojstven način jer se jedino tako upotpunjuju i obogaćuju oba sloja društva (Habermas, 2017b; Ricer, 2012).

\section{Odnos interesa i saznanja.}

Podruštvljenjavanje u svetu života i sistemu kao odvojenim, ali isprepletanim slojevima društva, vezano je za saznajne procese. Interesi su vodiči saznanja, određuju naučnu objektivnost (Habermas, 1975; Habermas, 1986) i determinante su mogućeg saznanja sveta (Habermas, 1980). Interes je oznaka za vezu između predmeta u stvarnosti za koji se interesujemo i između naše žudnje. Interesi imaju svoje uporište u životnim povezanostima (struktura rada i interakcije, društveno reprodukovani život), koje su istovremeno otelotvoreni kognitivni izraz nekadašnjih interesa, ali i ugrađene u sve ,nove” interese čime doprinose vođenju saznanja. Takođe, interesi su svezani sa delanjem u samorefleksiji (Habermas, 1975).

Time nijedan vid saznanja nije vrednosno neutralan, već je vođen interesima, pa realnost biva , istovremeno razotkrivena i konstituisana" kroz interese (Habermas, 1980: 15). Interesi ne postoje sami po sebi već nastaju u društvu i imaju ideološku funkciju. Spoznaja služi različitim interesima, a interesi su integralni deo spoznaje (Cohen et al., 2007; Habermas, 1980; Pešić, 1998). Određuju šta će biti prepoznato kao znanje - ne kao skupina parcijalnih informacija, već zapravo korpus saznanja koja reflektuju interese naučne zajednice koja je to znanje kokonstruisala (Cohen et al., 2007). Oni vode saznanje tako što su nužni uslovi mogućnosti iskustva, ,filteri” kroz koje saznajemo i učestvujemo u vaspitnoj stvarnosti. 
Kod Habermasa znanja korespondiraju sa interesima. Izdvaja tri sistema znanja i tri korespondirajuća interesa, pri čemu svakom sistemu znanja odgovara određeni tip nauke (Cohen et al., 2007; Habermas, 1975; Habermas, 1986; Halmi, 2005; Pešić, 1998; Terry, 1997) što može biti prikazano i kroz tabelu (Tabela 1).

Tabela 1

Odnos korespondirajućih interesa, znanja i nauka

\begin{tabular}{cccc}
\hline Interes & Fokus & Znanje & Korespondirajuće nauke \\
\hline $\begin{array}{c}\text { Tehnički } \\
\text { (empirijsko-analitički) }\end{array}$ & $\begin{array}{c}\text { predviđanje i } \\
\text { kontrola }\end{array}$ & analitičko & prirodne nauke i matematika \\
& & &
\end{tabular}

Praktični

(hermenutičko-

razumevajući)

Emancipatorski (kritičko-dijalektički)

razumevanje, humanističko hermeneutičke, društvene,
tumačenje,
kontekst

emancipacija, kritičko sloboda, demokratičnost

Terry „habermasovskom” znanju pridružuje neka nova značenja. Analitičkom znanju pridružuje znati činjenice, tj. sadržaj obrazovanja, hermenutičkom znanju pridružuje znati kako, tj. metodologiju, a kritičkom znanju pridružuje znati zašto, tj. obrazovnu politiku (Ryle, 1949; prema: Terry, 1997). U prilog tome, znanje posmatramo kroz tri sistema znanja gde ,informacije proširuju moć našeg tehničkog raspolaganja; interpretacije omogućuju orijentisanje delovanja pod zajedničkim tradicijama; a analize oslobađaju svest od zavisnosti od hipostaziranih moći” (Habermas, 1986: 124). Zadatak naučnika, teoretičara jeste da prepozna ove interese koji konstituišu tri njima korespondirajuće paradigme istraživanja, pozitivističku (normativnu), hermeneutičku (interpretativnu) i kritičku (Cohen et al., 2007) ili drugim rečima, paradigmu društvenog rada, paradigmu sporazumevanja, emancipatorsku paradigmu (Habermas, 1975; Habermas, 1988), ali i da postupa u skladu sa tim saznanjima.

\section{Komunikativna racionalnost.}

Racionalnost i znanje su usko povezani. Racionalost se odnosi na način na koji „subjekti sposobni za govor i delanje stiču i upotrebljavaju znanje” (Habermas, 2017a: 25). Habermas zagovara komunikativnu racionalnost, neprinudno učešće subjekata u komunikaciji u kojoj ih ujedinjuje snaga argumentativnog govora (Flivbjerg, 2012; 
Habermas, 2017a). Racionalnost iznetih izjava u komunikaciji prepoznaje se u odnosu na mogućnost da budu kritikovane i obrazlagane „kada i ukoliko otelovljuje pogrešivo znanje" (Habermas, 2017a: 27).

Habermas razlikuje dva tipa delovanja, instrumentalno i komunikativno, kao i njima korespondirajuće instrumentalno (tehničko) raspolaganje subjektivno centriranog uma usmereno ka postizanju nekog cilja, uspeha, radu, željenog stanja stvari, naspram komunikativnog sporazumevanja, koje je oličeno uglavnom kroz jezik (Habermas, 1975; Habermas, 1988; Habermas, 2017a).

Komunikativni um kao izraz komunikativne racionalnosti ima decentrirano, intersubjektivno razumevanje sveta (Habermas, 1988). Dešava se u neprinudnim uslovima, gde su učesnici oslobođeni od svakog vida moći, religijskog, metafizičkog uticaja i orijentisani ka racionalno motivisanom sporazumu (Habermas, 1988; Habermas, 2017a). Subjekat nije zapitan samo nad sobom kao stvaraocem, već je okrenut ka drugim podruštvljenim individuama koje se recipročno priznaju kroz jezik koji ima funkciju sporazumevanja i koordinacije delovanja (Habermas, 1988).

U centru teorije komunikativnog delovanja je jezičko sporazumevanje (Habermas, 2017a). Jezički znak koji govornik upotrebljava u komunikaciji u kojoj želi da se sporazume ima tri funkcije primene - kognitivnu (služi kao simbol za predstavljanje nečega), ekspresivnu (simptom je izražavanja samog govornika) $i$ apelativnu (signal je slušaocu za određene zahteve za delanjem) (Buhler, 1934; prema: Habermas, 2017a). Upravo je apelativna funkcija primene centralni element komunikativnog delovanja (Habermas, 1988) koje se odvija kroz komunikativnu praksu.

Kroz komunikativnu praksu se učesnici uveravaju u zajednički, deljeni svet života čiju ukupnost interpretacija donose oni sami (Habermas, 2017a). Sporazumevanje znači usaglašavanje između njih, subjekata koji su sposobni za govor i delanje (Habermas, 2017a), a ispostavlja se kao mehanizam koordinacije delovanja (Habermas, 2017a; Habermas, 2017b). Ova komunikativna praksa okrenuta je postizanju, održavanju i obnavljanju konsenzusa zasnovanog na intersubjektivnom priznavanju pretenzija na važenje koje su podložne kritici (Habermas, 2017a).

Učesnici koji deluju ka sporazumu zajednički definišu situaciju iz resursa sveta života (Habermas, 2017b). Situacija je ,isečak” iz sveta života determinisan nekom temom koja se ,javlja u vezi sa interesima i ciljevima (bar) jednog učesnika” (Habermas, 2017b: 164) i odnosi se na relevantne delove te situacije i planove usmerene ka ostvarivanju cilja nastale na osnovu njenog tumačenja (Habermas, 2017b). S obzirom da akti sporazumevanja koordiniraju delovanje, svoje individualne planove delovanja sagovornici usklađuju i sprovode na osnovu zajedničke definicije situacije (Habermas, 1988; Habermas, 2017a; Habermas, 2017b).

Argumentacija je vrsta govora kroz koju simetrični sagovornici na sistematizovan način tematizuju različite pretenzije na važenje određene izjave i ubeđuju sagovornike da prihvate određenu pretenziju na važenje (Habermas, 2017a), ali imaju jedinu motivaciju u kooperativnom traganju za istinom (Habermas, 2017a). Snaga argumena- 
ta sagledava se u odnosu na izvorni kontekst $\mathrm{u}$ opsegu $\mathrm{u}$ kom doprinose ciljevima određene oblasti, pa se to često naziva institucionalnim ispoljavanjem tipova argumentacije (npr. pravo, moral, nauka, umetnost...) (Habermas, 2017a). Ipak, Habermas govori o opštim komunikativnim pretpostavkama argumentacije, situaciji idealnog govora, situaciji govora koja je oslobođena nejednakosti, represije, svih spoljnih uticaja (npr. moć pojedinaca ili grupa), ličnih i/ili grupnih interesa u kojoj su učesnici komunikacije (sagovornici) racionalno motivisani. Racionalna motivacija u komunikaciji u situaciji idealnog govora se ispoljava kroz težnju sagovornika da postignu slobodnu i otvorenu komunikaciju kroz istinsko, otvoreno, nepristrasno razmatranje pitanja (Habermas, 2017a; Ricer, 2012). Jedina moć koja važi i odnosi pobedu u komunikaciji je snaga boljeg argumenta, a bolji argument je onaj argument koji se iznosi ubedljivije i pruža bolje dokaze (Habermas, 2017a; Flivbjerg, 2012; Ricer, 2012). Kada bolji argument ima prioritet, komunikacija vodi postizanju konsenzusa o normama koje su svim sagovornicima prihvatljive (Habermas, 2017a; Ricer, 2012; Terry, 1997).

Habermas prepoznaje tri nivoa reagovanja slušaoca na neku govornu radnju: 1. razumevanje izjave, 2. zauzimanje stava, 3. konsekvencija na nivou ponašanja (Habermas, 2017a). Govornim radnjama govornik izražava da neka izjava ima samo jednu pretenziju na važenje (saglasnost ili nesaglasnost) u odnosu na: 1. ispravnost (delovanje se upoređuje sa nekim normativnim kontekstom), 2. iskrenost (izražavanje subjektivnih doživljaja koji su u skladu sa stanjem stvari), 3. istinitost (govornik pretpostavlja važenje nekog iskaza pod datim uslovima) (Habermas, 2017a; Habermas, 2017b). Slušalac prihvata ili ne pretenziju datu govornim aktom koji je ilokutivan kroz sopstveni govorni akt koji ima formulaciju da ili ne uz dodatak glagola kojim iskazuje sa kojom sadržinom je saglasan/ne, a ukazuje i na garancije i obaveze koje proizilaze iz govornog akta. Npr. „Obećavam ti da ću sutra doći.” „Da, uzdam se u to.” (Habermas, 2017a: 337-338). Izjava koja ima ilokutivnu moć, može da ubedi slušaoca da se saglasi sa ponudom iznetom u njoj. Nasuprot tome, zauzimajući negativan stav, ne saglašavajući se sa nekom izjavom, slušalac iskazuje da osporava pretenziju/-e na važenje u odnosu na ispravnost, iskrenost $i$ istinitost (Habermas, 2017a).

Oznaka toga da su se učesnici u komunikaciji sporazumeli jeste da su se složili da je određeni iskaz regularan, dok saglasnost predstavlja „,intersubjektivno priznavanje pretenzije na važenje koju govornik zahteva za svoj iskaz" (Habermas, 2017b: 156), kako za eksplicitno istaknutu pretenziju na važenje, tako i za druge dve implicitno prisutne (Habermas, 2017b). U vezi sa tipom izjava svezane su različite pretenzije na važenje i njima korespondirajući koncept sveta. Npr. kod konstativnih govornih radnji (izjava, tvrđenje, objašnjavanje, pričanje, prikazivanje, razjašnjavanje...) slušalac priznaje/osporava pretenziju na propozicionalnu istinitost. Kod ekspresivnih govornih radnji (otkrivanje, priznavanje, obelodanjivanje...) sagovornik, slušalac priznaje/osporava pretenziju na iskrenost u samoreprezentaciji govornika. Kod regulativnih govornih radnji u kojima se pojavljuju elementarne namerne rečenice (npr. obećanja) ili elementarne rečenice zahvaljivanja (npr. zapovesti) slušalac priznaje/osporava pre- 
tenziju na normativnu ispravnost koju govornik pripisuje govornoj radnji (Habermas, 2017a). U svakom slučaju, ova komunikativno postignuta, racionalno motivisana saglasnost nije nametnuta od spolja putem nagrade ili prisile, već je suštinski prihvaćena kao važeća na osnovu zajedničkih uverenja (Habermas, 2017a; Habermas, 2017b).

\section{Kritičko razmatranje Habermasovih ideja u svetlu pedagogije}

Habermas je ostavio trag u istoriji filozofije, ali i u sociologiji, pravu, pedagogiji, drugim društvenim i prirodnim naukama. Vrednost njegovog rada jeste u tome što je nepokolebljivi, čak utopistički modernista, teoretičar koji veruje u univerzalno utemeljenje mišljenja, delanja i nauke kao nade u liberalnoj politici (Flivbjerg, 2012; Rorty, 1991). Njegovo delo ima i heurističku vrednost jer je mnogo pisao i podstakao je druge koji ne veruju u modernistički projekat da zauzmu stav i daju čak i oprečno mišljenje kao odgovor na njegove ideje.

Habermas veruje u modernističku nauku koja svoj smisao nalazi „u otkrivanju jedne velike priče o društveno-istorijskom razvoju, razvoju čoveka i njegovim fenomenima" (Radulović, 2016: 17). Kroz svakodnevnu komunikaciju sagovornika unutar sveta života u situaciji idealnog govora sagovornici se u nad- i intersubjektivnom procesu međusobno sporazumevaju i recipročno priznaju (Habermas, 1988). Znanje koje se ustanovi kroz ovaj intersubjektivni akumulativni proces stalno nadograđujućih, nastajućih konsenzusa u puno različitih situacija idealnog govora je vođeno navedenim interesima, $\mathrm{t}$. znanje je uvek interesno znanje u nekoj od tri paradigme.

Gledište o postojanju tri društveno konstruisana znanja zahvaljujući trima različitim interesima privlači pažnju, ali se smatra da je u pitanju preveliko pojednostavljivanje (Keat 1981; prema: Cohen et al., 2007). Ukazuje se da opredeljivanjem za jedno od tri vrste znanja, npr. analitičko znanje koje je usmereno ka represivnoj kontroli, istraživač mora da bude svestan mogućih implikacija onoga što pozitivizam nosi, standardizaciju, porast testiranja i nekada jezik kojim se implicitno ili eksplicitno ukazuje na to da učesnici imaju jednake šanse u obrazovanju (Apple, 2012a; 2014; prema: Radulović, 2016). Takođe, upitno je kako se sa jedne strane insistira na objektivnosti svih učesnika u dijalogu i mogućnosti da se moć ostavi po strani, a sa druge strane se u centar teorije stavljaju interesi koji vode saznanje i nisu vrednosno neutralni. Kada se zapitamo šta svi ovi podaci i uvid znače za pedagogiju, čini se da je važno imati u vidu postojanje ove tri vrste znanja kao najšireg, fundamentalnog okvira i dobro poznavati njihove odlike, jer se danas istraživač i istraživač-praktičar može opredeliti iz koje paradigme će sagledavati vaspitnu stvarnost, šta će odabrati za predmet istraživanja i što je još važnije, kako će predmet postaviti, kako će ga razumeti u svetlu svake od paradigmi, kako će dalje istraživati, ali i kako će razumeti pedagoška istraživanja koja čita, stručnjake, naučnike sa kojima se susreće.

Kada govorimo o prirodi trojako shvaćenog i kroz stalno akumulirajuće konsenzuse konstituisanog znanja, još jedna važna stavka koja je prisutna u nauci uopšte, 
pa i u pedagogiji je pogrešivost (Habermas, 2017a). Time znanje i nauka prate istu logiku mogućnosti opovrgavanja što svedoči u korist stava da u pedagogiji nema neupitne, jednom za svagda ustanovljene istine, već se znanje o vaspitanju gradi u intersubjektivnom procesu u naučnoj zajednici. Drugim rečima, za Habermasa istina sigurno jeste jedna naučna istina oko koje se naučna zajednica u ovom istorijskom trenutku dogovori, ali je ona promenljiva u odnosu na konsenzus učesnika u dijalogu jer je to njihova dogovorena stvarnost oko koje su se usaglasili.

Ako se za trenutak osvrnemo na savremenu nauku, jedan od značajnih međunarodnih, istraživačkih pedagoških projekata iz oblasti predškolske pedagogije Vrednosti u obrazovanju i skandinavskim vrićima: osnova za buduće obrazovanje (Values education in Nordic preschools: Basis of education for tomorrow) svoje utemeljenje nalazi u Habermasovim idejama. Kao rezultat projekta nastala su brojna empirijska i teorijska istraživanja članova istraživačkog tima iz Danske, Švedske, Norveške i sa Islanda dostupna putem sajta https://www.uis.no/research-and-phd-studies/research-areas/early-childhood-education-and-care/values-education-in-nordic-preschools/. U svojim istraživanjima usmereni su na razumevanje institucionalizovanog negovanja vrednosti u skandinavskim predškolskim ustanovama sa teorijskog, empirijskog i metodološkog aspekta (Values education in Nordic preschools, 2020). Postojanje ovakvih međunarodnih naučnih projekata u razvijenim zemljama koji se dosta u sistemskom smislu bave obrazovanjem na javnom planu, govori da su Habermasove ideje i dalje aktuelne što ćemo razmatrati i u tekstu koji sledi.

Brojni autori Habermasovom radu upućuju kritike zbog zapostavljanja nekih društvenih kategorija kao što su društveni pokreti, kulturne podele, klasa, etnička pripadnost, popularna kultura, identitet, rod (Cohen, 1995, Habermas, 1992b; prema: Flyvbjerg, 1998; Fraser, 1985, Ryan, 1992; prema: Flivbjerg, 2012). Ne prepoznaje ih kao obespravljene ili u nejednakom položaju u dijalogu. Zanemarivanje pitanja roda pripisuje se i Habermasovom shvatanju da su u društvu muškarci na pozicijama gde se odlučuje o važnim pitanjima (Fraser, 1985). Prigovara mu se da su mnogi društveni pokreti i obespravljene grupe kao što su žene svoja prava i status dobile upravo kroz borbu i aktivizam, a ne kroz dijalog koji sledi demokratsku proceduru i vodi konsenzusu (Wapner, 1994, Spinosa et al., 1997; prema: Flivbjerg, 2012). Postavlja se pitanje, da su razlike zaista minorne, da li bi danas veliki deo populacije imao pravo na obrazovanje, žene pravo glasa, mogućnost da rade itd.?

Ovim Habermas minimizira razlike koje postoje među učesnicima u vaspitno-obrazovnom procesu što može dovesti do uskraćivanja prilike da dijalog istinski bude oslobođen od upliva moći. Tadić pozivajući na Epla obrazlaže da se minimiziranjem razlika obnavljaju nejednakosti koje u društvu već postoje zato što škola ,učenike tretira kao jednake (jednake mogućnosti pristupu kulturnom kapitalu), na skriveni način favorizuje one koji su prethodno stekli jezičke i društvene kompetencije koje dominantna kultura podrazumeva" (Apple, 2012a; prema: Tadić, 2016: 261). 
Ovakvo razumevanje ne iznenađuje zato što Habermas duboko veruje da je priroda čoveka dobra i racionalna, a ne koristoljubiva i vođena nekim drugim ličnim interesima sem trima koji vode saznanje. Istina nije nametnuta kroz spoljnu kontrolu, proglašena ili dogovorena unutar neke „moćnije” grupe, već je dogovorena među ljudima u dijalogu kroz otvorenu komunikaciju i snagu boljeg argumenta. Demokratija se postiže kroz proceduralni govor unutar formalnih institucija. Sa druge strane, Flivbjerg misli da su ljudi složeniji od homo demokratikusa, da su po prirodi makijavelistički orijentisani i vešti da ,prevare sistem”, da procene mogućnosti ustava i rade na sopstvenu, individualnu i grupnu korist (Flivbjerg, 2012).

Neki autori smatraju da bi bilo neodrživo zamisliti institucije koje funkcionišu samo na osnovu konsenzusa i snage boljeg argumenta zato što se ne mogu svi sukobi rešavati kroz racionalnu argumentaciju (Bernstein, 1992), kao i da bi ovakva potpuno demokratska procedura sprečila institucije da funkcionišu operativno (Lübbe, 1995, Benhabib; 1990; prema: Flivbjerg, 2012). Zagovara se stav da moć u institucijama „uvek kruži kroz organizaciju sličnu mreži” i stvara znanje (Foucault, 1980; prema: Rodríguez, 2011: 143), pa saznavanje i znanje nikad nisu nezavisni od moći, već su isprepletani i postignuti kroz delovanje moći u organizacijama.

Fuko, Derida, Niče i Flivbjerg razumeju da se moć ne može poreći, da je prisutna i konstitutivna uvek, pa i u komunikaciji, empirijskim i normativnim istraživanjima (Flivbjerg, 2012). Moć se deli među učesnicima istraživanja, na primer u akcionim istraživanjima (Carr, Kemmis, 1986), ali Koen i saradnici misle da je to previše optimistično jer je u stvarnom društvenom životu uzaludno govoriti o velikim promenama koje kreću odozdo na gore i verovati da do njih zaista može doći (Cohen et al., 2007). Pritom Habermasu i prigovaraju da je politički mislilac koji malo poznaje realne političke procese, da ne razume dovoljno odnose moći, što je neophodno da bi moglo doći do neke promene (Flivbjerg, 2012).

Upitno je kako je ovaj proceduralni konsenzus ostvariv, do čega dovodi u obrazovnim institucijama imajući u vidu da unutar kulture obrazovnih institucija postoje i istovremeno nastaju formalni, neformalni, pisani i nepisani odnosi moći? Kako demokratske procedure komunikativne racionalnosti mogu da ne ostanu samo formalna mogućnost za dogovor ili predlog očekivanog dogovaranja? Kako učesnici tumače mogućnost dolaženja do konsenzusa koji je dogovorena istina za određenu zajednicu? Šta ako učesnici nemaju slična etička polazišta? Nekako se čini da uspostavljanje kulture obrazovnih institucija koje neguju komunikativnu racionalnost preuzima agensnost, postaje moć po sebi, mesto za iskazivanje moći boljeg argumenta.

Habermasovim idejama se zamera i političnost. Od istraživača se očekuje da bude bez ličnih interesa i vrednosno neutralan, što teoretičari tumače kao doprinos statusu quo i nečijoj agendi. Kako su usmereni na ideološki program oni svakako ideološki deluju što nije u skladu sa tradicionalnom vizijom objektivnog istraživača (Morisson, 1995a; prema: Cohen et al., 2007) koji nepristrasno sagledava, pristupa i tako ulazi u situaciju idealnog govora. Upitno je da li istraživač zaista može da ostane po 
strani i ne „upliće” moć u kritičkoj, emancipatorskoj paradigmi kada je on i agens promene u nekom, na primer akcionom pedagoškom istraživanju. Takođe, u savremenoj literaturi se o nastavniku govori ujedno kao o aktivisti i istraživaču sopstvene prakse (Apple, 2012a; prema: Radulović, 2016). U tom duhu, proces učenja se sagledava emancipatorski, individualno iskustvo učesnika vaspitno-obrazovnog procesa se uvažava (Tadić, 2016).

Komunikativno delovanje doprinosi formiranju ličnih identiteta svih učesnika i obnavljanju pripadnosti društvenim grupama (Habermas, 2017b). Sagovornici polaze od subjektivnih shvatanja idući ka intersubjektivnom jedinstvu sveta, pri čemu je intersubjektivno iznad subjektivnog, a svi kojih se određena tema, pitanje tiču mogu slobodno da doprinesu u procesu udruženog traganja za istinom koja je intersubjektivno validirana (Porter \& Porter, 2003). Ipak, Habermasu se upućuju kritike zbog relativizacije normi - nametanja konsenzualne istine kao objektivne zato što za principe kojima se vodi, normativna ispravnost, istinitost i istina (Habermas, 1988), kao i za određivanje boljeg argumenta, ne postoje jasni kriterijumi (Flivbjerg, 2012).

Flivbjerg se slaže sa Habermasom da postoji opšti princip i da snaga boljeg argumenta može da odnese prevagu, ali zagovara kontekstualno zavistan pogled na svet - različite interese koji važe za različite referentne grupe (Flivbjerg, 2012) od kojih oni (i kada žele) ne mogu da odstupe jer je moć agens znanja, a ne „sila” koju bi trebalo i koja se može ostaviti po strani ni tokom samog dijaloga, ni tokom akcije koja proizilazi kao rezultat dogovora u dijalogu.

Još jedna zamerka ide u smeru dekontekstualizacije istine. Problematizuje se shvatanje da sagovornici koji su iz različitog konteksta zaista mogu voditi dijalog u kome je istina određena na osnovu snage boljeg argumenta (Porter \& Porter, 2003). Jedno od otvorenih pitanja je i da li je onda istina univerzalna, referentna vrednost za sve ili je relativna, kontekstualno primerena? Samim tim, upitno je i da li se dijalog koji vodi konsenzusu može zloupotrebiti? Možda i sam Habermas ukazuje na to kroz pojam „obmanjivog konsenzusa” (Habermas, 1980: 23)? Kakve implikacije istina neosetljiva na kontekst ima u obrazovanju koje je uvek u kontekstu, prepoznaje i uvažava ga u nastavnom procesu, organizaciji i proučavanjima?

U obrazovanju, dijalog predstavlja ,način preispitivanja shvatanja sveta, građenja shvatanja sveta i konstruisanja samog sveta" (Radulović, 2016: 55) kroz mogućnost svih učesnika vaspitno-obrazovnog procesa da budu saslušani i da njihovo mišljenje doprinosi odlukama. Time, dijalog je karakteristika demokratije u obrazovanju za sve pojedince i grupe „odnosno način zajedničkog traganja za istinom o svetu, do koje niko ne može doći sam" (Freire, 2005; prema: Radulović, 2016: 55). Ostvaruje se kroz takozvane otvorene komunikativne prostore u kojima učesnici razmatraju teme, pitanja, dileme i orijentisani su ka postizanju konsenzusa. Često se vezuje za akciona istraživanja (Kemmis, 2001), ali se dijalog razume kao pristup celokupnom obrazovanju. 


\section{Zaključak}

Za pedagoge, vaspitače, nastavnike koji čitaju Habermasove ideje koje se odnose na teoriju komunikativnog delovanja brojna pitanja ostaju otvorena za promišljanje, što upućuje na značajne tačke za dalji dijalog i konkretne akcije, promene u praksi vaspitanja i obrazovanja. Na primer, upitno je da li proceduralnost u dijalogu zaista garantuje veću demokratičnost. Kako kontekstualno neosetljiv dijalog može istinski da omogućava prepoznavanje i slušanje ,glasa" svih učesnika, drugih i drugačijih mišljenja, stavova? Šta ako se učesnici slažu da oko nekih pitanja ne mogu da postignu konsenzus? Kako etički gledano ostaviti neko društveno, pedagoško pitanje po strani dok se vaspitna stvarnost neprestano menja i usložnjava? Možda je onda istina za tu referentnu grupu trenutno status quo. Zašto bi bilo ili ne bi bilo dobro da se moć ostavi po strani, izvan mogućnosti za agensnost $\mathrm{u}$ dijalogu, kad pod određenim okolnostima može biti i moralno opravdano ovladati njome?

Neka od retkih savremenih teorijskih i empirijskih istraživanja u predškolskoj pedagogiji koja su utemeljena na Habermasovoj teoriji komunikativnog delovanja (Emilson, 2018; Fugelsnes, 2018; Johansson et al., 2018) nas uveravaju da pitanja poput ovih mogu biti oslonac čitaocima, naučnicima i praktičarima, za potpunije razumevanje pedagoške teorije, prakse, ali i promišljeno delovanje na više nivoa: regionalnom i nacionalnom nivou obrazovne politike, sistema obrazovanja i vaspitanja, prakse na nivou predškolske ustanove, prakse na nivou vaspitne grupe, odnosa koje vaspitači, deca i drugi učesnici u vaspitno-obrazovnom procesu grade. Ohrabruju nas da u svom okruženju u dijalogu nastojimo da etički razmatramo ideje, mišljenja, stavove različitih sagovornika, ne prema društvenoj ulozi, određenim interesima ili poziciji moći, već samo na osnovu toga šta je bolji argument.

Na primer u nacionalnim predškolskim programima skandinavskih zemalja težište je na vrednostima kao što su demokratičnost, briga i ravnopravnost (Ringsmose, Kragh Müller, 2017; prema: Johansson et al., 2018). Kako vrednosti žive, nastaju i komuniciraju se u dijalogu, Habermasova teorija komunikativnog delovanja je inspirisala praktičare iz predškolskih ustanova $i$ istraživače da učestvujući u participativnom akcionom istraživanju kroz analizu dokumenata obrazovne politike, narative, pisanje dnevnika, video-snimanje, grupne, individualne intervjue i umetničke metode kao osnov za refleksiju sagledavaju kako da još potpunije razumeju, podrže i neguju vrednosti u institucionalnom predškolskom vaspitanju, u komunikaciji između dece i vaspitača (Emilson, 2018).

Takođe, važno je ukazati na empirijska istraživanja poput opsežne studije Kristin Fugelsnes (2018) koja se kroz analizu video-snimaka iz vrtića u Norveškoj bavila time kako se u institucionalnom predškolskom vaspitanju, u odnosu vaspitača i dece verbalno i neverbalno komunicira vrednost brige. U zaključnim razmatranjima ukazuje da je bez obzira na različito iskustvo odraslog i deteta, neophodno napraviti iskorak ka demokratičnijem komuniciranju vrednosti brige od brige o deci tokom koje 
je vaspitač ključna osoba koja brine o detetu, a dete prihvata da se o njemu brine odgovarajući kroz govor tela, gestove, poglede, prema brizi kao recipročnoj, gde odrasli preuzima posebnu vrstu odgovornosti da sasluša, odgovara, razgovara sa decom kroz reči, gestove, kontakt očima itd. Zapravo, čitaoca emprijskih istraživanja u publikaciji Johansson, E., Emilson, A., \& Puroila, A. M. (2018). Values Education in Early Childhood Settings: Concepts, Approaches and Practices. Cham: Springer International Publishing. može iznenaditi kako teorija komunikativnog delovanja nalazi svoje mesto, pruža epistemološki okvir, a time pomaže razumevanju, promišljanju i unapređivanju prakse predškolskog vaspitanja kroz prepoznavanje i razmatranje prisutnih i mogućih vrednosti u složenoj mreži odnosa u predškolskoj ustanovi.

Idući u svojoj epistemologiji od racionalnog $j a$ ka racionalnom mi, Habermas na neotklonjiv način veruje u mogućnost konsenzusa svih strana u dijalogu. Idealista, a možda i utopista, svojim idejama daje postojanu nadu u mogućnost zasnivanja velike, zajedničke teorije. Ohrabruje njegova nepokolebljiva vera u dobru prirodu čoveka, poverenje u institucije i uverenje da ljudi mogu da savladaju kolonizatora, sistemsko „čudovište” sa strukturama moći koje su zapravo sami napravili, upravo kroz negovanje otvorene komunikacije u kojoj je snaga boljeg argumenta jedina istinska moć, a time i agens znanja između pojedinaca, između i unutar institucija koje su formalno na „pozicijama moći”.

\title{
Ivana Prlić,
}

Sirmium College of Vocational Studies

for Preschool Teachers and Business Infrmatics

Sremska Mitrovica

\section{THEORY OF COMMUNICATIVE ACTION: CONTEXT FOR UNDERSTANDING THE NATURE OF KNOWLEDGE IN PEDAGOGY}

\begin{abstract}
The paper discusses theory of communicative action of Jürgen Habermas as a context for understanding the nature of knowledge in pedagogy. Starting from the ideas of the Frankfurt School of Critical Theory, Habermas considers that knowledge is led by three different interests: technical, practical and emancipatory. He advocates communicative rationality, the unforced participation of subjects in communication in which they are united by the power of argumentative speech. He believes that consensus is possible in a situation of ideal speech, free from all forms of external power, inequality and repression. The only power that is valid and brings victory in communication is the power of a better argument. The knowledge that is established through this
\end{abstract}


intersubjective accumulative process of consensuses constantly building upon themselves and emerging in many different situations of ideal speech is led by the stated interests, so knowledge is always interest led knowledge in one of the three paradigms. The paper further discusses the meaning of some Habermas' key ideas for pedagogy. The critiques that different authors direct to the theory of communicative action are discussed through bringing them into a relationship with certain attitudes in pedagogy. Accordingly, special attention is paid to understanding dialogue in education.

Key words: nature of knowledge, communicative rationality, consensus, dialogue in education

\section{Literatura}

Bernstein, R. J. (1992). The New Constellation: The Ethical-Political Horizons of Modernity/Postmodernity. Cambridge, MA: MIT Press.

Carr, W., Kemmis, S. (1986). Becoming Critical: Education, Knowledge and Action Research. Lewes: Falmer Press.

Cohen, J. L. (1995). Critical Social Theory and Feminist Critiques: the Debate with

Jurgen Habermas. In J. Meehan (Eds.), Feminists Read Habermas: Gendering the Subject of Discourse (pp. 57-91). New York: Routledge.

Cohen, L., Manion, L., \& Morrison, K. R. B. (2007). Metode istraživanja u obrazovanju. Jastrebarsko: Naklada Slap.

Emilson, A. (2018). A Dual Perspective and a Communicative Approach to Values Education in Early Childhood Education. In: E. Johansson, A. Emilson \& A. M. Puroila (Eds.), Values Education in Early Childhood Settings: Concepts, Approaches and Practices (pp. 55-67). Cham: Springer International Publishing.

Flivbjerg, B. (2012). Šta mogu društvene nauke: razlozi neuspeha i strategija za budućnost. Beograd: Službeni glasnik.

Flyvbjerg, B. (1998). Habermas and Foucault: Thinkers for Civil Society? The British Journal of Sociology, 49(2), 210-233.

Fraser, N. (1985). What's critical about critical theory?: The case of Habermas and gender. New German Critique, 13(35), 97-131.

Fugelsnes, K. (2018). Reciprocal Caring in ECEC Settings. In: E. Johansson, A. Emilson \& A. M. Puroila (Eds.), Values Education in Early Childhood Settings: Concepts, Approaches and Practices (pp. 187-198). Cham: Springer International Publishing.

Habermas, J. (1975). Saznanje i interes. Beograd: Nolit.

Habermas, J. (1980). Teorija i praksa: socijalnofilozofske studije. Beograd: BIGZ.

Habermas, J. (1986). Tehnika i znanost kao "ideologija". Zagreb: Školska knjiga.

Habermas, J. (1988). Filozofski diskurs moderne: dvanaest predavanja. Zagreb: Globus. 
Habermas, J. (2017a). Teorija komunikativnog delovanja I: racionalnost delovanja $i$ društveno racionalizovanje. Novi Sad: Akademska knjiga.

Habermas, J. (2017b). Teorija komunikativnog delovanja II: teorija funkcionalističkog uma. Novi Sad: Akademska knjiga.

Halmi, A. (2005). Strategije kvalitativnih istraživanja u primijenjenim društvenim znanostima. Jastrebarsko: Naklada Slap.

Johansson, E., Emilson, A., \& Puroila, A. M. (2018). Values Education in Early Childhood Settings: Concepts, Approaches and Practices. Cham: Springer International Publishing.

Johansson, E., Emilson, A. \& Puroila, A. M. (2018). Values in Nordic Preschools: Setting the Scene. In: E. Johansson, A. Emilson \& A. M. Puroila (Eds.), Values Education in Early Childhood Settings: Concepts, Approaches and Practices (pp. 1-9). Cham: Springer International Publishing.

Kemmis, S. (2001). Exploring the relevance of critical theory for action research: Emancipatory action research in the footsteps of Jürgen Habermas. In P. Reason $\&$ H. Bradbury (Eds.), Handbook of action research: Participative inquiry and practice (pp. 91-102). London: SAGE.

Pavićević, Đ. (2011). Kritička teorija društva Frankfurtske škole. Godišnjak Fakulteta političkih nauka, 5(5), 49-66.

Pešić, M. (1998). Pedagogija u akciji - metodološki priručnik. Beograd: IPA.

Porter, R., Porter, K. A. (2003). Habermas and the pragmatics of communication: a Deleuze-Guattarian critique. Social Semiotics, 13(2), 129-145.

Radulović, L. (2016). Slike o nastavniku - između moderne i postmoderne. Beograd: IPA i CON, Filozofski fakultet.

Ricer, Dž. (2012). Savremena sociološka teorija i njeni klasični koreni. Beograd: Službeni glasnik.

Rodríguez, J. P. (2011). Foucault with Habermas: toward a complementary critical reading of modernity. Universidad Central de Chile: Facultad de Ciencias Políticas y Administración Pública.

Rorty, R. (1991). Habermas and Lyotard on postmodernity. In: Essays on Heidegger and Others: Philosophical Papers (pp. 164-176). Cambridge: Cambridge University Press. doi:10.1017/CBO9780511609039.011

Tadić, A. (2016). Model intelektualne avanture: ka razumevanju Djuijevog progresivizma iz perspektive kritičkih koncepcija vaspitanja. Pedagogija, 71(3), 251268.

Terry, P. R. (1997). Habermas and education: knowledge, communication, discourse. Curriculum Studies, 5(3), 269-279. doi: 10.1080/14681369700200019

Values education in Nordic preschools: Basis of education for tomorrow. Retrieved 21 September 2020 from https://www.uis.no/research-and-phd-studies/researchareas/early-childhood-education-and-care/values-education-in-nordic-preschools/ 